\title{
Validation of the Hungarian version of the Humor Styles Questionnaire (HSQ-H)
}

\author{
JUDIT BODA-UJLAKY ${ }^{1}$ - LÁSZLÓ SÉRA² - \\ FERENC KÖTELES ${ }^{3}$ - ATTILA SZABO ${ }^{3,4 *}$ \\ ${ }^{1}$ Department of Psychology and Sport Psychology, Hungarian University of Physical \\ Education, Budapest, Hungary \\ ${ }^{2}$ Doctoral School, University of Pécs, Pécs, Hungary \\ ${ }^{3}$ Institute of Health Promotion and Sport Sciences, Eötvös Loránd University, Budapest, \\ Hungary \\ ${ }^{4}$ Institute of Psychology, Eötvös Loránd University, Budapest, Hungary
}

(Received: 24 October 2016, accepted: 27 April 2017)

Background and objectives: Humor style reflects the way in which people use humor in their daily lives. Its investigation is paramount in humor research and it is also important in the context of various psychological investigations and mental health research. Due to the lack of a relevant tool, the aim of the current inquiry was to validate the Hungarian version of the Humor Styles Questionnaire (HSQ; Martin et al., 2003). Methods: A total of 425 male and female volunteers' completed the Hungarian version of the Humor Styles Questionnaire (HSQ-H). Results: The HSQ-H has emerged to be a significantly shorter (22 items vs. 32 items of the original English HSQ), but nevertheless reliable, instrument. The four subscales, affiliative- (6 items), self-enhancing- (6-items), self-defeating- (5 items), and aggressive humor (5 items), all had acceptable internal consistencies, ranging from (Cronbach's alpha) .72 to .85. The HSQ-H differentiated young adults (18-21 years) from adults and older adults (36 years and over), and those with lower and higher education levels, but did not yield statistically significant gender differences, or differences that could be linked to the living area of the respondents. Intercorrelations of the subscales were similar to those reported in validation research performed in other languages. Conclusions: It is concluded that the HSQ-H is a short and reliable instrument for assessing humor styles in the Hungarian population, but the further testing of its psychometric properties is warranted.

Keywords: humor, humor style, affiliation, aggressive, self-defeating, self-enhancing

\footnotetext{
* Corresponding author: Prof. Attila Szabo, Institute of Health Promotion and Sport Sciences, Eötvös Loránd University, 1117 Budapest, Hungary, Bogdánfy Ödön u. 10. E-mail: szabo.attila@ ppk.elte.hu
} 


\section{Introduction}

Humor is a ubiquitous form of human communication (Martineau, 1972) that involves verbal and nonverbal elements, which most often yield "positive cognitive or affective response from listeners" (Crawford, 1994, p. 57). It is widely assumed that humor is indeed positive and, therefore, it is an important component of the human well-being (Leist \& Müller, 2013). Investigating the use of humor can contribute to our knowledge about human cognitive and emotional processes, social relationships, mental and physical health. Therefore, there is substantial interest in psychology in this topic (for a review see Ruch, 2008). The first established measurement of humor preference, in relation to personality traits, dates back to 1966 (the Institute for Personality and Ability Testing (IPAT) Humor Test; Cattel \& Tollefson, 1966).

Over a decade ago, the Humor Styles Questionnaire (HSQ; Martin, Puhlik-Doris, Larsen, Gray, \& Weir, 2003) was developed on the basis of sound theoretical grounds by focusing on the adaptive and maladaptive aspects of humor (Dozois, Martin, \& Bieling, 2009), because the earlier studies could not address the relationship between humor and health, while humor (and its measures) was conceptualized as a heterogeneous, so called umbrella construct (for a review see Martin, 2007). The HSQ measures both aspects of humor on two subscales. The adaptive facet of humor is gauged by the 'affiliative- and self-enhancing humor' subscales, while the maladaptive use of humor is assessed with the 'aggressive and selfdefeating humor' subscales. Nowadays, when it comes to measuring psychological aspects of humor, HSQ is the most commonly used tool (as based on North and South American, or various European and Asian samples, for a review see Martin, 2007).

Affiliative humor is characterized by funny verbal manifestations, such as telling jokes, or making fun of the situation, or even ridiculing oneself to cheer up a social situation and to reduce tension (Lefcourt, 2001). This type of humor is tolerant, entertaining, and non-offensive to others, and, therefore, generates interpersonal attraction and social cohesion. Accordingly, this humor style may be linked to joy, extraversion, happy mood, self-esteem, easy-going relationship, satisfaction, and positive affect (Martin et al., 2003).

Another adaptive humor style is self-enhancing humor that is characterized by joyful and humorous look at various life events and relationships, even if those may normally create stress or frustration (Vela, Booth-Butterfield, Wanzer, \& Vallade, 2013). This humor style is linked to psychological coping (Martin, 1996), which substantiates the use of humor for the regulation of emotions (Dixon, 1980; Martin, Kuiper, Olinger, \& 
Dance, 1993) and is rather consistent with Freud's (1928) view on humor as a defense mechanism against negative emotions while keeping in perspective a threatening life event. Unlike affiliative humor, this style is more self-oriented, and it is inversely related to negative emotions such as depression, anxiety, and, more generally, neuroticism, while it is directly related to the openness to experience, self-esteem, and psychological wellbeing (Martin et al., 2003).

Aggressive humor involves a certain degree of sarcasm, cynicism, making fun of others or discriminately putting down others (Martin et al., 2003). People using this humor style influence, or manipulate, others with an inferred emotional threat of ridicule (Janes \& Olson, 2000). Aggressive humor may also be appraised as ego-boosting and enhancing one's feelings of superiority, or maintaining and/or securing a place in the social hierarchy, but objectively it is often detrimental, provocative, and antisocial (Leist \& Müller, 2013). This style mirrors a tendency to use humor without empathy, or consideration of the possible impact on others (e.g., racist, sexist, occupation-linked humor) and includes the compulsive use of humor in which one cannot control the impulse to say jokes that may hurt or alienate others (Martin et al., 2003). Aggressive humor acts as a cathartic stimulus to aggressive responses (Berkowitz, 1970). According to Martin et al. (2003), this style of humor is positively associated with neuroticism, hostility, anger, and aggression, while it is negatively linked to relationship satisfaction, agreeableness, and conscientiousness.

Self-defeating humor represents an excessive self-disparaging humor aimed at amusing others by doing silly things or saying funny things about the self. The purpose is to get attention and to flow into a conversation depicting oneself as self-critical, cynical about the self, and easy going person. This dimension of humor may involve a defensive denial and/or the tendency to use humor for hiding one's negative emotions and/or avoiding the confrontation with a problem (Kubie, 1971). While people who score high on this humor dimension may appear as amusing (e.g., "clowns"), there is an underlying emotional emptiness, avoidance, and low self-appreciation behind the use of such humor (Fabrizi \& Pollio, 1987). This style of humor may be positively related to neuroticism and negative emotions such as depression and anxiety, and negatively linked to overall satisfaction in social relationships, psychological well-being, and selfesteem (Martin et al., 2003).

In the current study, we undertook the validation of the Hungarian version of the HSQ, because at this time the Hungarian literature lacks a psychometrically valid instrument that could assess humor styles and, consequently, their association with various aspects of mental health and/ or psychological well-being. Indeed, no other published and validated 
measurement tool - for assessing humor use - is available in Hungarian. Since humor styles are conceptualized alongside a 2x2 matrix, positive (affiliative and self-enhancing) and negative (aggressive and self-defeating), self-directed (self-enhancing and self-defeating) and other-directed (affiliative and aggressive) styles, we hypothesized that these four dimensions of humor would be relatively dependent, except for aggressive and self-enhancing, and affiliative and self-defeating comparisons, that would prove to be independent.

\section{Method}

\subsection{Participants}

The HSQ-H was administered in three different studies, with different data collection methods. In one study (Boda-Ujlaky, Horváth, Záhorszki, \& Séra, 2013) we investigated the relationship between aggression and humor styles, with 153 participants, of which 58 males belonged to the imprisoned, experimental sample, the rest formed the control (21 females, 74 males, recruited via the acquaintances of the first two authors). The imprisoned sample filled the questionnaires under the supervision of their psychologists, while the control sample completed an internet-based survey. The next study (Séra \& Boda-Ujlaky, 2013) investigated the common belief that obese people are more cheerful, therefore out of 102 participants 60 had a higher body mass index (BMI) than 25 which is the limit of considering someone as overweight, 42 had normal BMI (11 males, 91 females). The participants were found in a weight-loss group, and all of them filled in a paper-and-pencil questionnaire at home. The third study measured the link between creativity and humor styles (Séra, Boda-Ujlaky, \& Gyebnár, 2015), there were 159 participants, 57 males and 102 females, mostly (50.9\%) university students. Students of a Psychology of humor class were asked to spread questionnaires among their friends and family, as a course requirement. Detailed instructions were given.

The full sample consisted of volunteering participants $(N=425)$. Their mean age was 31.6 years, $S D=13.51$ years. Ethical clearance for the research was obtained in all studies from the Research Ethics Board of a large Hungarian University. Most of the volunteers came from large and small urban areas $(81.9 \%)$. Villages and small communities were represented by less than a fifth of the sample $(18.1 \%)$. Participants were rather welleducated as nearly three quarters of them possessed a higher education certificate $(72.3 \%)$. The sample was adequately balanced between men 
(55.5\%) and women (44.5\%). All participants consented to taking part in the study and completed the Hungarian version of the HSQ on a totally voluntary basis. For the sample description, see Table 1.

Table 1. Characteristics of the participants

\begin{tabular}{|c|c|c|c|}
\hline Gender & $\begin{array}{l}\text { Mean age }(\mathrm{SD}) \\
\text { years* }\end{array}$ & $\begin{array}{l}\text { Location of permanent } \\
\text { residence }\end{array}$ & Level of Education** \\
\hline Men & $\begin{array}{l}33.18 \\
(13.51)\end{array}$ & $\begin{array}{l}\text { capital city and } \\
\text { agglomeration } N=136 \\
\text { county capital } N=55 \\
\text { town } N=29 \\
\text { municipality } N=15 \\
\text { village } N=0\end{array}$ & $\begin{array}{l}\text { primary school } N=24 \\
\text { secondary school } N=63 \\
\text { GCSE/maturity exam } N=100 \\
\text { professional training } N=20 \\
\text { university/college degree or } \\
\text { higher } N=28\end{array}$ \\
\hline Women & $\begin{array}{l}29.93 \\
(13.25)\end{array}$ & $\begin{array}{l}\text { capital city and } \\
\text { agglomeration } N=105 \\
\text { county capital } N=51 \\
\text { town } N=20 \\
\text { municipality } N=9 \\
\text { village } N=3\end{array}$ & $\begin{array}{l}\text { primary school } N=7 \\
\text { secondary school } N=23 \\
\text { GCSE/maturity exam } N=109 \\
\text { professional training } N=16 \\
\text { university/college degree or } \\
\text { higher } N=33\end{array}$ \\
\hline
\end{tabular}

Note: *Men were older than women $(F(1,421)=6.16, p=.013)$;

**The two genders differed in education level $\left(\chi^{2}(4)=24.24, p<.001\right)$.

\subsection{Materials}

The Humor Styles Questionnaire (HSQ; Martin et al., 2003) was translated into Hungarian then translated back to English by several members of the research team. Once the final consensus on the contextual meaning of the translated questions has been reached, the current version of the Hungarian Humor Styles Questionnaire (HSQ-H) was finalized (Appendix A). The questionnaire originally contained 32 items, 8 on each 4 subscales, the items are rated on a 7-point Likert scale.

\subsection{Procedure}

The volunteering participants completed a paper and pencil form, or an online form of the questionnaire at their convenience at various flexible data-collecting venues. In other words, the participants did not need to travel or dislocate from their natural place. The completion of the 
questionnaire took about ten minutes. In addition, participants who consented to taking part in the study were required to provide their age, gender, location of their permanent residence (city, village, etc.) and level of education (see Table 1).

\subsection{Statistical analysis}

Data were analyzed using the SPSS v.21 software. Similarly to the procedure followed by the authors of the English version (Martin et al., 2003), the items were subjected to principal component analysis (PCA) with varimax rotation. Multivariate analyses of variance (MANOVA) were used to examine gender and age differences on the subscales of the HSQ-H. Correlations were carried out between participants' age and HSQ-H scores on the four subscales.

\section{Results}

According to the results of the PCA, the first four factors (eigenvalues: $7.435 ; 3.625 ; 2.610 ; 1.631$ ) explained $47.8 \%$ of the total variance. Factor loadings are presented in Table 2. Overall, a structure similar to those of the English version emerged. Items 5, 8, 11, 13, 16, 19, and 28 were excluded as they more or less equally loaded on more than one factors. Item 27 was excluded, because it belongs to the Self-Defeating Humor scale in the original version (both statistically and contextually), however, it loaded on the Aggressive Humor scale in the Hungarian version. As we intended to develop a Hungarian version with scales of approximately equal length, two additional items from the Self-Enhancing Humor scale (26 and 30 as their factor loadings were the lowest) were removed. Scales in the final Hungarian version are as follows. The Affiliative Humor scale consists of six items $(1,9,17,21,25,29)$ with good internal consistency (Cronbach's alpha $=.826$; all item-total correlations are above .47$)$. The Self-Enhancing Humor scale consists of six items $(2,6,10,14,18,22)$ with good internal consistency (Cronbach's alpha $=.853$; item-total correlations $>.50$ ). The SelfDefeating Humor scale consists of five items $(4,12,20,24,32)$ with acceptable internal consistency (Cronbach's alpha $=.756$; item-total correlations > .49). Finally, the Aggressive Humor scale consists of five items $(3,7,15,23,31)$ with acceptable internal consistency (Cronbach's alpha $=.723$; item-total correlations $>.40$ ). 
Table 2. Factor loadings of the items (principal component analysis with varimax rotation; values under .1 are not presented)

\begin{tabular}{|c|c|c|c|c|}
\hline & $\begin{array}{c}\text { Factor 1 } \\
\text { (Affiliative } \\
\text { Humor) }\end{array}$ & $\begin{array}{c}\text { Factor } 2 \\
\text { (Self-Enhancing } \\
\text { Humor) }\end{array}$ & $\begin{array}{c}\text { Factor } 3 \\
\text { (Self-Defeating } \\
\text { Humor) }\end{array}$ & $\begin{array}{c}\text { Factor } 4 \\
\text { (Aggressive } \\
\text { Humor) }\end{array}$ \\
\hline HSQ1 & .652 & & -.109 & \\
\hline HSQ2 & .300 & .677 & & \\
\hline HSQ3 & .140 & .191 & .295 & .568 \\
\hline HSQ4 & & & .635 & \\
\hline HSQ5 & .581 & .440 & & \\
\hline HSQ6 & .326 & .649 & & \\
\hline HSQ7 & & & & .653 \\
\hline HSQ8 & .404 & .114 & .345 & -.201 \\
\hline HSQ9 & .582 & .124 & .104 & .132 \\
\hline HSQ10 & .121 & .788 & .127 & \\
\hline HSQ11 & -.309 & -.182 & .382 & \\
\hline HSQ12 & & & .708 & \\
\hline HSQ13 & .665 & .417 & .103 & .103 \\
\hline HSQ14 & .374 & .708 & .149 & \\
\hline HSQ15 & & & & .714 \\
\hline HSQ16 & .365 & & .392 & .348 \\
\hline HSQ17 & .748 & .230 & & .115 \\
\hline HSQ18 & & .790 & & \\
\hline HSQ19 & .105 & .267 & .348 & .137 \\
\hline HSQ20 & & & .742 & .106 \\
\hline HSQ21 & .738 & .189 & .168 & \\
\hline HSQ22 & .221 & .543 & -.162 & \\
\hline HSQ23 & .246 & -.125 & & .629 \\
\hline HSQ24 & & & .677 & .116 \\
\hline HSQ25 & .699 & .183 & & .104 \\
\hline
\end{tabular}


Table 2. (continued)

\begin{tabular}{|l|c|c|c|c|}
\hline & $\begin{array}{c}\text { Factor 1 } \\
\text { (Affiliative } \\
\text { Humor) }\end{array}$ & $\begin{array}{c}\text { Factor 2 } \\
\text { (Self-Enhancing } \\
\text { Humor) }\end{array}$ & $\begin{array}{c}\text { Factor 3 } \\
\text { (Self-Defeating } \\
\text { Humor) }\end{array}$ & $\begin{array}{c}\text { Factor 4 } \\
\text { (Aggressive } \\
\text { Humor) }\end{array}$ \\
\hline HSQ26 & .239 & .687 & & .517 \\
\hline HSQ27 & & .416 & .315 & .241 \\
\hline HSQ28 & -.107 & .216 & -.133 & \\
\hline HSQ29 & .720 & .523 & & .684 \\
\hline HSQ30 & & -.119 & & \\
\hline HSQ31 & .145 & .109 & .626 & \\
\hline HSQ32 & .120 & & & \\
\hline
\end{tabular}

A multivariate analysis of variance of gender differences, with the newly validated HSQ-H, did not yield a statistically significant multivariate effect for the four subscales of the questionnaire. However, statistically significant negative correlations emerged between participants' age and affiliative humor $(r=.26, p<.001)$ as well as aggressive humor $(r=.32, p<.001)$. The inter-correlations among the four subscales ranged from $r=.005$ to $r=.47$ (see Table 3).

Table 3. Correlations between the four subscales of the HSQ-H

\begin{tabular}{|l|c|c|c|c|}
\hline & $\begin{array}{c}\text { Affiliative } \\
\text { Humor }\end{array}$ & $\begin{array}{c}\text { Self-enhancing } \\
\text { Humor }\end{array}$ & $\begin{array}{c}\text { Self-defeating } \\
\text { Humor }\end{array}$ & $\begin{array}{c}\text { Aggressive } \\
\text { Humor }\end{array}$ \\
\hline Affiliative Humor & - & $.470^{*}$ & .080 & $.190^{*}$ \\
\hline Self-enhancing Humor & & - & $.148^{*}$ & .005 \\
\hline Self-defeating Humor & & & - & $.261^{*}$ \\
\hline
\end{tabular}

Note: ${ }^{*} p<.05$

These correlations were followed up by grouping participants using a conservative median split (excluding those in the middle $33.3 \%$ of the datarange (those who were between 22 and 36 years of age) as recommended Gelman and Park (2008). In fact we eliminated more than $38 \%$ of the middle range data, which resulted in a young adult group aged $18-21$ years $(N=$ 
$131,31.0 \%$ of the data) and a mixed adult and older adult group aged 36 years and above ( $N=129,30.6 \%$ of the data). We then exposed these groups to a two (groups) by four (dependent measures: the four subscales of the HSQ-H) multivariate analysis of variance (MANOVA), which yielded a statistically significant between-subjects multivariate effect (Pillai's trace $=$ $.220, F(4,255)=17.97, p<.001$, effect size, partial ETA squared $\left.\left(\eta_{p}^{2}\right)=.220\right)$. The follow-up univariate tests have revealed that the two age-groups, or the young and older adults, differed statistically significantly from each other in affiliative humor $\left(F(1,258)=16.83, p<.001, \mathrm{\eta}_{\mathrm{p}}^{2}=.061\right)$ and aggressive humor $\left(F(1,258)=50.94, p<.001, \eta_{\mathrm{p}}{ }^{2}=.165\right)$. A statistically non-significant trend was observed in self-defeating humor $\left(F(1,258)=3.30, p=.070, \mathrm{\eta}_{\mathrm{p}}{ }^{2}=\right.$ .165). No between-groups differences were observed in self-enhancing humor. These results are illustrated in Table 4.

Table 4. Means and standard deviations (SD) in four measures of humor styles reflecting the four subscales of the HSQ-H in two age-groups. The effect sizes (Cohen's d) are also shown for the statistically significant groupdifferences.

\begin{tabular}{|l|l|c|l|c|}
\hline & $\begin{array}{c}\text { Aged 18-21 } \\
\mathbf{( N = 1 3 1 )}\end{array}$ & $\begin{array}{c}\text { Aged 36 or } \\
\text { older } \\
(\mathbf{N = 1 2 9 )}\end{array}$ & \multicolumn{1}{|c|}{$p$} & Cohen's $\boldsymbol{~}$ \\
\hline Affiliative humor & $35.49(5.04)$ & $32.29(7.32)$ & $<.001$ & 0.51 \\
\hline Self-enhancing humor & $28.30(7.16)$ & $29.33(7.22)$ & $=.247(\mathrm{~ns})$ & 0.14 \\
\hline Self-defeating humor & $17.34(5.80)$ & $16.02(5.85)$ & $=.070$ (trend) & 0.23 \\
\hline Aggressive humor & $19.57(4.80)$ & $15.07(5.37)$ & $<.001$ & 0.88 \\
\hline
\end{tabular}

Note: $\mathrm{ns}=$ statistically not significant; trend $=$ close to, but it did not reach the conservative level of statistical significance.

We also tested the effects of geographical location and level of education in the use of humor styles. While the former did not yield any statistically significant differences, the education level by humor style MANOVA has revealed a statistically significant multivariate effect (Pillai's trace $=.117$, $F(16,1672)=3.16, p<.001$, effect size, partial ETA squared $\left.\left(\eta_{\mathrm{p}}{ }^{2}\right)=.029\right)$ that was due to differences in affiliative humor $\left(F(4,418)=5.57, p=.001, \eta_{\mathrm{p}}{ }^{2}=\right.$ $.051)$ and aggressive humor $\left(F(4,418)=6.54, p=.001, \eta_{\mathrm{p}}{ }^{2}=.059\right)$. These results are summarized in Table 5. 
Table 5. Means and standard deviations (SD) in four measures of humor styles reflecting the four subscales of the HSQ-H in five education-level groups

\begin{tabular}{|l|c|c|c|c|c|}
\hline & $\begin{array}{c}\text { Group } \boldsymbol{a} \\
(\mathbf{N = 3 1 )}\end{array}$ & $\begin{array}{c}\text { Group } \boldsymbol{b} \\
\mathbf{( N = 8 6 )}\end{array}$ & $\begin{array}{c}\text { Group } \boldsymbol{c} \\
(\mathbf{N = 2 0 9 )}\end{array}$ & $\begin{array}{c}\text { Group } \boldsymbol{d} \\
\mathbf{( N = 3 6 )}\end{array}$ & $\begin{array}{c}\text { Group } \boldsymbol{e} \\
(\mathbf{N = 6 1 )}\end{array}$ \\
\hline Affiliative & 31.51 & 34.93 & 34.93 & 33.56 & 31.52 \\
humor & $(8.24)^{\mathrm{c}}$ & $(5.14)^{\mathrm{e}}$ & $(5.90)^{\mathrm{ae}}$ & $(5.49)$ & $(6.98)^{\mathrm{bc}}$ \\
\hline Self-enhancing & 28.42 & 28.52 & 28.72 & 30.53 & 28.43 \\
humor & $(7.49)$ & $(7.43)$ & $(7.26)$ & $(5.59)$ & $(6.54)$ \\
\hline Self-defeating & 17.06 & 16.81 & 17.08 & 16.50 & 15.90 \\
humor & $(4.98)$ & $(5.76)$ & $(5.84)$ & $(6.35)$ & $(5.83)$ \\
\hline Aggressive & 14.39 & 17.55 & 18.96 & 17.17 & 16.23 \\
humor & $(5.24)^{\mathrm{c}}$ & $(5.28)$ & $(5.65)^{\mathrm{ae}}$ & $(5.20)$ & $(6.02)^{\mathrm{c}}$ \\
\hline
\end{tabular}

Note: a) primary school, b) secondary school, c) GCSE/maturity exam, d) professional training, and e) university/college degree or higher. The superscripts show that those groups were statistically significantly different (at $p<.05$, at least) from the superscript-indicated group as based on Bonferroni post-hoc tests

As the sample was merged from different studies, we ought to report the original internal consistencies, item-total correlations. The internal consistency (Cronbach's alpha) of the affiliative subscale in the three studies varied between .86 and .90 , item-total scores ranged from .36 to .84 . Cronbach's alpha for the aggressive subscale ranged from .51 to .71 , itemtotal scores from .20 to .72 . The self-enhancing humor subscale showed high internal consistency from .85 to .86 , while item-total correlations were between .40 and .78 . The self-defeating humor subscale showed lower internal consistency from .68 to .80 , while item-total correlations were between .38 and .74. In the original samples, items 9, 11, 19, 28 and 30 had low item-total correlations, in the merged sample items 5, 8, 11, 13, 16, 19 and 28 had low factor loadings. The common items in the list belong to the aggressive (item 11,19) and the self-defeating (item 28) subscales, i.e. to negative humor usage, while item 30 was removed to ensure the equal length of the scales (and it was eliminated because of the lowest factor loading). Hence, the merged sample does not differ significantly from the original ones.

\section{Discussion}

The results demonstrate that the Hungarian version (22 items - Appendix B) of the HSQ traps adequately the four humor styles assessed by the original English version (Martin et al., 2003). The internal consistency 
(Cronbach's alpha) of the four subscales ranged from acceptable (.72) to good (.85). These values are in accord with the validation report of the original scale (.77 to .81; Martin et al., 2003); with the Italian version of the scale, ranging from .50 to .85 (Sirigatti, Penzo, Giannetti, \& Stefanile, 2014); with the German version of the scale, ranging from .70 to .87 (Ruch \& Heintz, 2016); with Arabic version of the HSQ, ranging from .55 to .79 (Taher, Kazarian, \& Martin, 2008), as well as with the Belgian (French) version of the scale, ranging from .70 to .75 (Saroglou \& Scariot, 2002).

The intercorrelations observed between the four subscales of the HSQ-H are similar to those found in validation studies of other national versions. In the German study (Ruch \& Heintz, 2016) statistically significant correlations between affiliative and self-enhancing humor $(r=.39$ vs. .47 in the current work), affiliative- and aggressive humor (.23 vs. .19 here), affiliative- and self-defeating (.10 vs. .08 here), and aggressive and self-defeating (.31 vs. .26) were found. Similarly, the results of the Italian validation study (Sirigatti et al., 2014) showed positive and significant correlations between affiliativeand self-enhancing humor (from $r=.39$ to .26 in different samples vs. .47 for the whole sample here), between affiliative- and aggressive humor (from $r=$ .16 to .34 in different samples, vs. .19 for the whole sample here), between self-enhancing and aggressive humor (for males and young adults $r=.29 \mathrm{vs}$. .005 for the whole in our work), and between self-enhancing- and selfdefeating humor (for males $r=.19$ vs. .15 for the whole sample here). Finally, the between-subscales correlations obtained in the Arabic validation study (Taher et al., 2008) of the HSQ are also in accord with the values obtained in our current work: affiliative- and self-enhancing humor (.41 vs. .47 here), affiliative- and aggressive humor (.10 vs. .19 here), affiliative- and selfdefeating humor (.19 vs. .08 here), self-enhancing- and aggressive humor -.01 vs. .005 here), self-enhancing- and self-defeating humor (.21 vs. .15 here), and self-defeating and aggressive humor (.36 vs. .26 here). These results indicate that the four subscales share their variance to some extent and have a conceptual overlap (since humor styles are conceptualized alongside a $2 \times 2$ matrix, positive [affiliative and self-enhancing] and negative [aggressive and self-defeating], self-directed [self-enhancing and selfdefeating] and other-directed [affiliative and aggressive]), the HSQ-H is showing the greatest share of variance between affiliative humor and selfenhancing humor $(22 \%)$, which is close to the values obtained for the German (15\%), Italian (up to $15 \%$ ) and the Arabic (17\%) versions of the questionnaire. These findings may not be surprising in the light of the conceptual definition of the two subscales. As it was hypothesized, the two opposing constructs (i.e. aggressive and self-enhancing; and affiliative and self-defeating) proved to be independent in our sample, hence the measuring tool seems to have a proper construct validity. 
In contrast to the original developmental study (Martin et al., 2003), the German (Ruch \& Heintz, 2016) and the Italian study (Sirigatti et al., 2014), that found gender differences on the aggressive humor style subscale (the original one by Martin et al. 2002 found a difference on self-defeating humor subscale, as well), we did not find gender differences in any of the four subscales of the HSQ-H. These findings indicate either that in Hungary there is no difference between men and women when using aggressive humor, i.e. the male norms are privileged, or in this relatively well-educated sample the humor usage of males are lower than it could be in a more representative sample. Moreover, in the original samples it was the aggressive humor subscale that showed the lowest Cronbach's alpha scores, which may be the least valid subscale of the questionnaire. Consequently, the lack of gender differences on the HSQ-H aggressive humor subscale may need further clarification with respect to the aggressive humor practices of Hungarian men and women.

The results showed that younger adults scored higher on affiliative- and aggressive humor, in contrast to middle-aged adults and older adults. These findings are consistent with the past reports from the literature (e.g., Martin et al., 2003; Sirigatti et al., 2014). However, unlike in the German validation study of the HSQ (Ruch \& Heintz, 2016), in which the age differences were small, in the current work they were medium in affiliative humor and large in aggressive humor (refer to Table 4). Similarly to the German research, self-enhancing humor increased while self-defeating humor decreased with age, however the former was statistically not significant and the latter only approached statistical significance. Therefore, the current results support the claim of Martin et al. (2003) that older adults may resort less affiliative and aggressive humor, which may be linked to a more restricted social life in contrast to the young adults and/or university students.

With respect to the level of education, some differences were noted in affiliative- and aggressive humor. Interestingly, those with low (primary school) and high (university/college degree or higher) education exhibited less affiliative humor than those in the mid-range. A similar trend has emerged in aggressive humor style (see Table 5). To date, in the literature there are no reports about the relationship between humor styles and level of education. Nevertheless, this finding merits further research attention. In the interim, a possible, but highly speculative explanation can be that those with low and high levels of education may have a lower affiliation need (belief that they cannot achieve, or have already achieved) and express aggressiveness via other channels than humor. Still another possible explanation is that the interpretation of the items of this scale differs in these groups from those with an average level of education. 
The study has some limitations. The data comes from different studies with different data collection strategies, the results were very similar across the studies. Moreover, the sample was not representative, included either relatively well-educated, or imprisoned populations, further research is needed to affirm the validity of the scale in a more representative population, and the test-retest reliability also needs to be determined.

In conclusion, the HSQ-H appears to be an adequate tool for measuring humor styles, but its validity deserves more investigation. The tool needs to be further tested in relation to individuals' sense of humor and subjective well-being as well. Sensitivity analysis should be determined in future studies in context of humor appraisal and humor situations. Systematic evaluation of gender differences in humor styles appears to be warranted.

\section{References}

Berkowitz, L. (1970). Aggressive humor as a stimulus to aggressive responses. Journal of Personality and Social Psychology, 16(4), 710-717.

Boda-Ujlaky, J., Horváth, A., Záhorszki, I., \& Séra, L. (2013). „Always look on the bright side of life”. Az agresszív humor kedvelése és az agressziv személyiségvonás kapcsolata a humorstílussal és a gelotofóbiával. In A. T. Litovkina, P. Bartha, \& K. Vargha (Szerk.), Sokszinü humor (157-169). Budapest: Tinta Kiadó

Cann, A., \& Matson, C. (2014). Sense of humor and social desirability: Understanding how humor styles are perceived. Personality and Individual Differences, 66, 176-180.

Cattell, R.B., \& Tollefson, D.L. (1966). The IPAT humor test of personality. Champaign, IL: Institute of Personality and Ability Testing

Crawford, C.B. (1994). Theory and implications regarding the utilization of strategic humor by leaders. The Journal of Leadership Studies, 1(4), 53-68.

Dixon, N.F. (1980). Humor: A cognitive alternative to stress? In I.G. Sarason, \& C.D. Spielberger (Eds.), Stress and anxiety, Vol.7. (281-289).Washington, DC: Hemisphere

Dozois, D.J., Martin, R.A., \& Bieling, P.J. (2009). Early maladaptive schemas and adaptive/ maladaptive styles of humor. Cognitive Therapy and Research, 33(6), 585-596.

Freud, S. (1928). Humour. International Journal of Psychoanalysis, 9, 1-6.

Gelman, A., \& Park, D.K. (2008). Splitting a predictor at the upper quarter or third and the lower quarter or third. The American Statistician, 62(4), 1-8. Doi:10.1198/000313008X366226

Lefcourt, H.M. (2001). Humor: The psychology ofliving buoyantly. New York: Kluwer Academic Publishers.

Leist, A.K., \& Müller, D. (2013). Humor types show different patterns of self-regulation, self-esteem, and well-being. Journal of Happiness Studies, 14(2), 551-569.

Martin, R.A. (2007). The psychology of humor: An integrative approach. Burlington, MA: Elsevier

Martin, R.A., Kuiper, N.A., Olinger, L., \& Dance, K.A. (1993). Humor, coping with stress, self-concept, and psychological well-being. Humor; International Journal of Humor Research. 6(1), 89-104.

Martin, R.A., Puhlik-Doris, P., Larsen, G., Gray, J., \& Weir, K. (2003). Individual differences in uses of humor and their relation to psychological well-being: Development of the Humor Styles Questionnaire. Journal of Research in Personality, 37(1), 48-75. 
Martineau, W.H. (1972). A model of the social functions of humor. In J. Goldstein, \& P. McGhee (Eds.), The psychology of humor (101-125). New York: Academic Press

Ruch, W. (2008). The psychology of humor. In V. Raskin (Ed.), The Premier of Humor Research, Berlin: Mouton de Gruyter

Ruch, W., \& Heintz, S. (2016). The German version of the humor styles questionnaire: psychometric properties and overlap with other styles of humor. Europe's Journal of Psychology, 12(3), 434-455.

Séra, L. \& Boda-Ujlaky, J. (2013). „Vaskos humor”. Vizsgálat a humor és az elhízás kapcsolatáról. In A.T. Litovkina, P. Bartha, \& K. Vargha (Szerk.), Sokszinü humor (181-192). Budapest: Tinta Kiadó

Séra, L., Boda-Ujlaky J., \& Gyebnár, V. (2015). A humorstílus és a kreativitás különböző aspektusainak összefüggései. Magyar Pszichológiai Szemle, 70(2), 295-312.

Sirigatti, S., Penzo, I., Giannetti, E., \& Stefanile, C. (2014). The humor styles questionnaire in Italy: Psychometric properties and relationships with psychological well-being. Europe's Journal of Psychology, 10(3), 429-450.

Saroglou, V., \& Scariot, C. (2002). Humor Styles Questionnaire: Personality and educational correlates in Belgian high school and college students. European Journal of Personality, 16(1), 43-54.

Taher, D., Kazarian, S.S., \& Martin, R.A. (2008). Validation of the Arabic Humor Styles Questionnaire in a community sample of Lebanese in Lebanon. Journal of Cross-Cultural Psychology, 39(5), 552-564.

Vela, L.E., Booth-Butterfield, M., Wanzer, M.B., \& Vallade, J.I. (2013). Relationships among humor, coping, relationship stress, and satisfaction in dating relationships: Replication and extension. Communication Research Reports, 30(1), 68-75.

\section{Acknowledgements}

Mr. Domján Ferenc, pioneer of the Hungarian Laughter Yoga movement, is thanked for his comments and active interest in the current work. Prof. Róbert Urbán is thanked for his advise on statistical methods.

\section{Division of labor}

J. B-U. took part in designing the research, collecting the data, writing the Methods section, and contributed to the writing of other parts of the paper, too. She also assumed an active role in revising the final draft of the paper. L. S. played an important role in the original conceptualization of the research and planning, as well as coordinating the data collection. F. K. conducted the principal components analysis along with some other statistical analyses and drafted the tables. A. Sz. researched the background literature, wrote up the literature review (Introduction section), and a large part of the Discussion section. He also assumed responsibility for the publication process of the report. 


\section{Conflict of Interests Statement}

The authors have no conflict of interest to declare.

\section{Appendix A. The Humor Styles Questionnaire (Original translation from Martin et al., 2003)}

\section{Humor Stílus Kérdőív}

Az emberek nagyon sokféleképpen érzékelik és fejezik ki a humort. Az alábbi listán állítások találhatók, amelyek a humorra adott reakciókat írják le. Kérem, gondosan olvassa el az összes állítást, és karikázással jelölje, hogy mennyire ért egyet vele! Kérjük, válaszoljon minél őszintébben! Használja az alábbi skálát:

\begin{tabular}{|c|c|c|c|c|c|c|}
\hline $\mathbf{1}$ & $\mathbf{2}$ & $\mathbf{3}$ & $\mathbf{4}$ & $\mathbf{5}$ & $\mathbf{6}$ & $\mathbf{7}$ \\
\hline $\begin{array}{c}\text { Egyáltalán } \\
\text { nem értek } \\
\text { egyet }\end{array}$ & $\begin{array}{c}\text { Inkább } \\
\text { nem értek } \\
\text { egyet }\end{array}$ & $\begin{array}{c}\text { Kis- } \\
\text { mértékben } \\
\text { nem értek } \\
\text { egyet }\end{array}$ & $\begin{array}{c}\text { Semleges } \\
\text { vagyok/ } \\
\text { nem tudok } \\
\text { állást } \\
\text { foglalni }\end{array}$ & $\begin{array}{c}\text { Kis- } \\
\text { mértékben } \\
\text { egyetértek }\end{array}$ & $\begin{array}{c}\text { Inkább } \\
\text { egyetértek }\end{array}$ & $\begin{array}{c}\text { Teljesen } \\
\text { egyetértek }\end{array}$ \\
\hline
\end{tabular}

\begin{tabular}{|r|l|c|}
\hline 1. & Általában nem nevetek vagy viccelődöm sokat másokkal. & 1234567 \\
\hline 2. & Ha levertséget érzek, humorral általában fel tudom vidítani magam. & 1234567 \\
\hline 3. & Ha valaki hibázik, gyakran ugratom emiatt. & 1234567 \\
\hline 4. & $\begin{array}{l}\text { Többször hagyom, hogy nevessenek rajtam vagy mulatságosnak } \\
\text { találjanak, mint kellene. }\end{array}$ & 1234567 \\
\hline 5. & $\begin{array}{l}\text { Nem kell sokat fáradoznom azon, hogy másokat megnevettessek - } \\
\text { természetemnél fogva humoros személy vagyok. }\end{array}$ & 1234567 \\
\hline 6. & $\begin{array}{l}\text { Ha magamban is vagyok, gyakran szórakoztatnak az élet } \\
\text { abszurditásai. }\end{array}$ & 1234567 \\
\hline 7. & Az embereket soha nem támadja vagy bántja humorérzékem. & 1234567 \\
\hline 8. & $\begin{array}{l}\text { Gyakran én is gúnyolódom magamon, ha ez a családomat } \\
\text { és a barátaimat megnevetteti. }\end{array}$ & 1234567 \\
\hline 9. & $\begin{array}{l}\text { Ritkán sikerül másokat megnevettetnem rólam szóló mókás } \\
\text { történetekkel. }\end{array}$ & 1234567 \\
\hline 10. & $\begin{array}{l}\text { Ha ideges vagy szomorú vagyok, általában próbálok } \\
\text { valami vicces dolgot felfedezni a szituációban, hogy jobban érezzem } \\
\text { magam. }\end{array}$ & \\
\hline
\end{tabular}




\begin{tabular}{|c|c|c|}
\hline 11. & $\begin{array}{l}\text { Ha vicceket vagy mulatságos dolgokat mondok, általában } \\
\text { nem érdekel, hogy mások hogyan fogadják. }\end{array}$ & 1234567 \\
\hline 12. & $\begin{array}{l}\text { Gyakran próbálom az emberekkel megkedveltetni magam azáltal, } \\
\text { hogy vicces dolgokat mondok a gyengeségeimról, baklövéseimról } \\
\text { vagy hibáimról. }\end{array}$ & 1234567 \\
\hline 13. & Sokat nevetek és viccelődöm a barátaimmal. & 1234567 \\
\hline 14. & $\begin{array}{l}\text { A humoros életfelfogásom megvéd attól, hogy túlságosan ideges } \\
\text { vagy depressziós legyek a dolgok miatt. }\end{array}$ & 1234567 \\
\hline 15. & $\begin{array}{l}\text { Nem szeretem, amikor az emberek a humort mások kritizálására } \\
\text { vagy megalázására használják. }\end{array}$ & 1234567 \\
\hline 16. & Ritkán mondok mulatságos dolgokat, hogy megalázzam magam. & 1234567 \\
\hline 17. & $\begin{array}{l}\text { Általában nem szeretek vicceket mesélni vagy az embereket } \\
\text { szórakoztatni. }\end{array}$ & 1234567 \\
\hline 18. & $\begin{array}{l}\text { Ha magam vagyok és szomorú, megpróbálok valami mulatságosra } \\
\text { gondolni, hogy felvidítsam magam. }\end{array}$ & 1234567 \\
\hline 19. & $\begin{array}{l}\text { Néha valami olyannyira mókás dologra gondolok, hogy muszáj } \\
\text { elmondanom, még akkor is, ha ez nem a helyzethez illő. }\end{array}$ & 1234567 \\
\hline 20. & $\begin{array}{l}\text { Gyakran túlzásba viszem saját magam megalázását, } \\
\text { amikor próbálok viccelődni vagy mókás lenni. }\end{array}$ & 1234567 \\
\hline 21. & Szeretem megnevettetni az embereket. & 1234567 \\
\hline 22. & $\begin{array}{l}\text { Ha szomorú vagy ideges vagyok, általában elvesztem } \\
\text { a humorérzékemet. }\end{array}$ & 1234567 \\
\hline 23. & $\begin{array}{l}\text { Soha nem nevetek ki másokat, még akkor sem, ha minden barátom } \\
\text { ezt teszi. }\end{array}$ & 1234567 \\
\hline 24. & $\begin{array}{l}\text { Ha családdal vagy barátokkal vagyok, gyakran én vagyok } \\
\text { az egyetlen, akivel mások viccelődnek vagy akit ugratnak. }\end{array}$ & 1234567 \\
\hline 25. & Ritkán mesélünk vicceket a barátaimmal. & 1234567 \\
\hline 26. & $\begin{array}{l}\text { Tapasztalatom szerint egy helyzet szórakoztató oldalát nézni } \\
\text { hatékony problémamegoldó eszköz. }\end{array}$ & 1234567 \\
\hline 27. & $\begin{array}{l}\text { Ha nem kedvelek valakit, gyakran megalázás céljából viccelődöm } \\
\text { rajta vagy ugratom őt. }\end{array}$ & 1234567 \\
\hline 28. & $\begin{array}{l}\text { Ha problémáim vannak vagy boldogtalan vagyok, gyakran } \\
\text { palástolom tréfálkozással, ezért a legközelebbi barátaim sem tudják } \\
\text { igazán, mit érzek. }\end{array}$ & 1234567 \\
\hline 29. & $\begin{array}{l}\text { Általában nem jut eszembe semmi szellemes dolog, ha társaságban } \\
\text { vagyok. }\end{array}$ & 1234567 \\
\hline
\end{tabular}




\begin{tabular}{|c|l|c|}
\hline 30. & $\begin{array}{l}\text { Nem szükséges, hogy emberekkel legyek körülvéve ahhoz, hogy jól } \\
\text { szórakozzak - általában találok dolgokat, amelyeken nevetni tudok, } \\
\text { még ha egyedül is vagyok. }\end{array}$ & 1234567 \\
\hline 31. & $\begin{array}{l}\text { Még ha valami nagyon mulatságosnak is túnik, nem nevetek rajta és } \\
\text { nem viccelődöm vele, ha ezzel valakit megbántok. }\end{array}$ & 1234567 \\
\hline 32. & $\begin{array}{l}\text { Azért hagyom, hogy mások nevessenek rajtam, mert ilyen módon } \\
\text { tudom családomat és barátaimat felvidítani. }\end{array}$ & 1234567 \\
\hline
\end{tabular}

\section{Appendix B. The Humor Styles Questionnaire Hungarian version (HSQ-H)}

\section{Humor Stílus Kérdőív}

Az emberek nagyon sokféleképpen érzékelik és fejezik ki a humort. Az alábbi listán állítások találhatók, amelyek a humorra adott reakciókat írják le. Kérem, gondosan olvassa el az összes állítást, és karikázással jelölje, hogy mennyire ért egyet vele! Kérem, válaszoljon minél őszintébben! Használja az alábbi skálát:

\begin{tabular}{|c|c|c|c|c|c|c|}
\hline $\mathbf{1}$ & $\mathbf{2}$ & $\mathbf{3}$ & $\mathbf{4}$ & $\mathbf{5}$ & $\mathbf{6}$ & $\mathbf{7}$ \\
\hline $\begin{array}{c}\text { Egyáltalán } \\
\text { nem értek } \\
\text { egyet }\end{array}$ & $\begin{array}{c}\text { Inkább } \\
\text { nem } \\
\text { értek } \\
\text { egyet }\end{array}$ & $\begin{array}{c}\text { Kis- } \\
\text { mértékben } \\
\text { nem értek } \\
\text { egyet }\end{array}$ & $\begin{array}{c}\text { Semleges } \\
\text { vagyok/ } \\
\text { nem tudok } \\
\text { állást } \\
\text { foglalni }\end{array}$ & $\begin{array}{c}\text { Kis- } \\
\text { mértékben } \\
\text { egyetértek }\end{array}$ & $\begin{array}{c}\text { Inkább } \\
\text { egyetértek }\end{array}$ & $\begin{array}{c}\text { Teljesen } \\
\text { egyetértek }\end{array}$ \\
\hline
\end{tabular}

\begin{tabular}{|r|l|c|}
\hline 1. & Általában nem nevetek vagy viccelódöm sokat másokkal.* & 1234567 \\
\hline 2. & $\begin{array}{l}\text { Ha levertséget érzek, humorral általában fel tudom vidítani } \\
\text { magam. }\end{array}$ & $\mathbf{1 2 3 4 5 6 7}$ \\
\hline 3. & Ha valaki hibázik, gyakran ugratom emiatt. & 1234567 \\
\hline$\underline{4 .}$ & $\begin{array}{l}\text { Többször hagyom, hogy nevessenek rajtam vagy mulatságosnak } \\
\text { találjanak, mint kellene. }\end{array}$ & $\underline{1234567}$ \\
\hline $\mathbf{5 .}$ & $\begin{array}{l}\text { Ha magamban is vagyok, gyakran szórakoztatnak az élet } \\
\text { abszurditásai. }\end{array}$ & $\mathbf{1 2 3 4 5 6 7}$ \\
\hline 6. & Az embereket soha nem támadja vagy bántja humorérzékem.* & 1234567 \\
\hline 7. & $\begin{array}{l}\text { Ritkán sikerül másokat megnevettetnem rólam szóló mókás } \\
\text { történetekkel.* }\end{array}$ & 1234567 \\
\hline
\end{tabular}




\begin{tabular}{|c|c|c|}
\hline 8. & $\begin{array}{l}\text { Ha ideges vagy szomorú vagyok, általában próbálok valami vicces } \\
\text { dolgot felfedezni a szituációban, hogy jobban érezzem magam. }\end{array}$ & 1234567 \\
\hline$\underline{9}$. & $\begin{array}{l}\text { Gyakran próbálom az emberekkel megkedveltetni magam azáltal, } \\
\text { hogy vicces dolgokat mondok a gyengeségeimról, baklövéseimröl } \\
\text { vagy hibáimról. }\end{array}$ & $\underline{1234567}$ \\
\hline 10. & $\begin{array}{l}\text { A humoros életfelfogásom megvéd attól, hogy túlságosan ideges } \\
\text { vagy depressziós legyek a dolgok miatt. }\end{array}$ & 1234567 \\
\hline 11. & $\begin{array}{l}\text { Nem szeretem, amikor az emberek a humort mások kritizálására } \\
\text { vagy megalázására használják.* }\end{array}$ & 1234567 \\
\hline 12. & $\begin{array}{l}\text { Általában nem szeretek vicceket mesélni vagy az embereket } \\
\text { szórakoztatni.* }\end{array}$ & 1234567 \\
\hline 13. & $\begin{array}{l}\text { Ha magam vagyok és szomorú, megpróbálok valami mulatságosra } \\
\text { gondolni, hogy felvidítsam magam. }\end{array}$ & 1234567 \\
\hline 14. & $\begin{array}{l}\text { Gyakran túlzásba viszem saját magam megalázását, } \\
\text { amikor próbálok viccelődni vagy mókás lenni. }\end{array}$ & $\underline{1234567}$ \\
\hline 15. & Szeretem megnevettetni az embereket. & 1234567 \\
\hline 16. & $\begin{array}{l}\text { Ha szomorú vagy ideges vagyok, általában elvesztem } \\
\text { a humorérzékemet.* }\end{array}$ & 1234567 \\
\hline 17. & $\begin{array}{l}\text { Soha nem nevetek ki másokat, még akkor sem, ha minden barátom } \\
\text { ezt teszi.* }\end{array}$ & 1234567 \\
\hline 18. & $\begin{array}{l}\text { Ha családdal vagy barátokkal vagyok, gyakran én vagyok } \\
\text { az egyetlen, akivel mások viccelődnek, vagy akit ugratnak. }\end{array}$ & $\underline{1234567}$ \\
\hline 19. & Ritkán mesélünk vicceket a barátaimmal.* & 1234567 \\
\hline 20. & $\begin{array}{l}\text { Általában nem jut eszembe semmi szellemes dolog, } \\
\text { ha társaságban vagyok.* }\end{array}$ & 1234567 \\
\hline 21. & $\begin{array}{l}\text { Még ha valami nagyon mulatságosnak is tünik, nem nevetek rajta } \\
\text { és nem viccelödöm vele, ha ezzel valakit megbántok.* }\end{array}$ & 1234567 \\
\hline$\underline{22 .}$ & $\begin{array}{l}\text { Azért hagyom, hogy mások nevessenek rajtam, mert ilyen módon } \\
\text { tudom családomat és barátaimat felvidítani. }\end{array}$ & $\underline{1234567}$ \\
\hline
\end{tabular}

Affiliative Humor scale Self-Enhancing Humor scale Self-Defeating Humor scale Aggressive Humor scale items: $1,7,12,15,19,20$ (shaded) items: 2, 5, 8, 10, 13, 16 (bold) items: 4, 9, 14, 18, 22 (underlined) items: 3, 6, 11, 17, 21 (italics)

Rating the HSQ-H: Add subscale items after rating reversely the items with a star $\left(^{*}\right)$ 


\title{
A Humor Stílus Kérdőív magyar változatának (HSQ-H) validálása
}

\author{
BODA-UJLAKY JUDIT - SÉRA LÁSZLÓ - KÖTELES FERENC - \\ SZABO ATTILA
}

\begin{abstract}
Elméleti háttér és célkitüzés: A humor stílus a humor mindennapi használatának jellemző módját jelenti. A különféle humor stílusok vizsgálata elsőrendủ fontossággal bír a humorkutatásban, ám más pszichológiai kutatási területeken és a mentális egészség vonatkozásában is van létjogosultsága. Mivel magyar nyelven nem állt rendelkezésre megfelelő mérőeszköz, vizsgálatunk célja a Humor Stílus Kérdőív (Humor Styles Questionnaire, HSQ; Martin et al., 2003) magyar változatának elkészítése és validálása volt. Módszerek: A HSQ magyar változatát (HSQ-H) összesen 425 önkéntes töltötte ki. Eredmények: A HSQ magyar változata az eredeti 32-tételes angol verziónál rövidebb (22-tételes) mérőeszköz. A négy alskála (affiliatív humor, 6 tétel; önmegerősító humor, 6 tétel; önvédő humor, 5 tétel; agresszív humor, 5 tétel) elfogadható belső konzisztenciával (Cronbach-alfa: 0,72-0,85) bír. Életkori és iskolázottsági különbségeket sikerült kimutatni, nemi és lakóhelyi különbségeket viszont nem. Az alskálák interkorrelációi a más nyelvi változatok esetében leírtakhoz hasonlóan alakultak. Következtetések: A HSQ-H a különböző humor stílusok rövid és megbízható mérőeszközének bizonyult. A kérdőív alaposabb megértéséhez további pszichometriai vizsgálatok szükségesek.
\end{abstract}

Kulcsszavak: humor, humor stílus, affiliáció, agresszív, önvédő, önmegerősítő 